QUALITY

Volume 8, Nomor 2, 2020, 303-318

\title{
Dampak Pandemi Covid-19 terhadap Eksistensi Pendidik di Era Digital
}

\author{
Yogik Delta Hermawan \\ IAIN Kudus, Indonesia \\ yogikdelta85@gmail.com
}

\begin{abstract}
Abstrak
Artikel ini bertujuan untuk menggambarkan peran seorang pendidik, tantangan yang dihadapi, hingga eksistensinya di era digital sekaligus di tengah pandemi Covid-19 yang melanda Indonesia. Penelitian ini menggunakan metode kualitatif, yaitu mendeskripsikan fakta-fakta dan fenomena yang terjadi di lapangan. Peran seorang pendidik masih sangat vital dan tetap dibutuhkan meskipun derasnya arus digitalisasi sekaligus dampak adanya pandemi Covid19. Pemanfaatan pembelajaran dengan menggunakan teknologi mengharuskan pendidik untuk meningkatkan kompetensinya. Guna menyikapi hal tersebut, terdapat beberapa hal yang harus dilakukan oleh seorang pendidik. Di antaranya, seorang pendidik harus mengikuti perkembangan teknologi, memberikan pembelajaran yang relevan dengan peserta didik, membangun pondasi pendidikan karakter yang kokoh, aktif mengamati perkembangan budaya populer, hingga aktif meneliti. Semua komponen tersebut harus dilakukan secara beriringan dan maksimal. Melihat fakta di atas, dapat ditegaskan bahwa kehadiran seorang pendidik di era digital sebagai dampak adanya Covid- 19 masih sangat diperlukan, utamanya dalam hal transfer of value di samping juga transfer of knowledge.
\end{abstract}

Kata Kunci: Pandemi, Eksistensi Pendidik, Era Digital 


\begin{abstract}
This article aims to describe the role of an educator, the challenges it faces, and its existence in the digital era as well as in the midst of the Covid-19 pandemic that has hit Indonesia. This study uses qualitative methods, which describe the facts and phenomena that occur in the field. The role of an educator is still very vital and is still needed despite the rapid flow of digitalization as well as the impact of the Covid-19 pandemic. The use of learning using technology requires educators to improve their competence. In order to respond to this, there are several things that an educator must do. Among other things, an educator must follow technological developments, provide relevant learning to students, build a strong character education foundation, actively observe the development of popular culture, and actively research. All these components must be carried out simultaneously and maximally. Looking at the facts above, it can be emphasized that the presence of an educator in the digital era as a result of Covid-19 is still very much needed, especially in terms of transfer of value as well as transfer of knowledge.
\end{abstract}

Keywords: Pandemic, Educator Existence, Digital Era

\title{
A. Pendahuluan
}

Mc Leod dalam Muhibbin, pendidik adalah A person whose occupation is teaching others. Tanpa kehadiran pendidik dapat dipastikan kegiatan belajarmengajar tidak akan berjalan sebagaimana mestinya. Pendidik adalah tenaga professional yang bertugas merencanakan dan melaksanakan proses pembelajaran; melakukan pembimbingan; melakukan pelatihan; menilai hasil pembelajaran; serta melakukan penelitian dan pengabdian kepada masyarakat, terutama bagi pendidik pada perguruan tinggi. Melihat pengertian di atas, semakin membuktikan bahwa peran pendidik memang harus ada. Pendidik era sekarang dengan era dahulu, tentu mempunyai perbedaan yang sangat signifikan. Utamanya dalam konteks tantangan terhadap perkembangan zaman (Muhibbin, 2016: 220).

Dewasa ini, pendidik dihadapkan pada perkembangan dunia teknologi yang begitu massif dan sangat pesat. Hampir semua lingkup kehidupan di masyarakat bersentuhan dengan teknologi. Apakah ini kebetulan, tentu tidak. Karena zaman sekarang adalah zaman teknologi atau sering disebut dengan istilah "Era Digital". Teknologi berasal dari bahasa Prancis "La Teknique" yang artinya semua proses 


\section{Yogik Delta Hermawan}

yang dilaksanakan dalam upaya untuk mewujudkan segala sesuatu secara rasional. Tidak hanya itu, teknologi merupakan hasil daya cipta dari kemampuan manusia. Yang pada gilirannya akan membentuk dan menciptakan sebuah komunitas baru (Haris, 2017: 34-37). Melihat fenomena terkait perkembangan teknologi yang begitu luar biasa, dan akhirnya memberikan dampak bagi dunia pendidikan. Mau tidak mau dunia pendidikan harus menyikapi era digital ini dengan arif dan bijaksana. Menghadapi adalah jalan yang harus ditempuh, daripada menghindari. Salah satu kuncinya adalah dengan mempersiapkan sumber daya manusia pendidikan yang memang benar-benar berkualitas. Mengapa hal ini penting, karena pendidik merupakan ujung tombak suksesnya sebuah pendidikan. Intinya adalah seorang pendidik harus mampu dan siap menghadapi berbagai macam dinamika yang ada.

Dunia pendidikan Indonesia saat ini sedang mengalami tantangan luar biasa selain perkembangan teknologi, yaitu adanya pandemi Covid-19. Akibat pandemi ini, seluruh kegiatan kependidikan di Indonesia di hentikan sementara waktu atau lebih tepatnya belajar dari rumah. Tentu hal ini berdampak bagi pendidik dan peserta didik. Menurut keterangan dari Menteri Pendidikan Nadiem Makarim dalam kompas.com, program belajar dari rumah merupakan salah satu bentuk upaya Kemendikbud bersama pemerintah agar kegiatan belajar-mengajar dapat terus berjalan. Ini merupakan salah satu cara dalam memutus mata rantai penyebaran Covid-19 di Indonesia. Nadiem juga menyatakan bahwa cara ini merupakan salah satu bentuk merdeka belajar bagi peserta didik (Kompas.com: 2020).

Kondisi demikian, tentu diperlukan pendidik yang benar-benar matang, baik dalam hal mental maupun kompetensinya. Oleh karena itu, rumusan masalah dalam penelitian ini di antaranya bagaimanakah eksistensi pendidik pada masa pandemi Covid-19 dan era digital ? serta bagaimanakah cara untuk meningkatkan eksistensi dan kompetensi pendidik pada masa pandemi Covid-19 dan era digital? Sehingga 
penelitian dirumuskan dengan judul "Dampak Pandemi Covid-19 Terhadap

Eksistensi Pendidik Di Era Digital”.

\section{B. Pembahasan}

Abad ke-21 merupakan sebuah abad dimana dunia seperti berada dalam genggaman. Dunia terasa milik kita, semuanya bisa dijangkau hanya dengan berdiam diri dengan memainkan gadget yang kita miliki. Itulah abad 21, semuanya serba dimudahkan. Manusia cenderung “dimanjakan" oleh teknologi. Tidak terbantahkan bahwa perkembangan teknologi pada abad ini begitu cepat dan masif. Perkembangan tersebut memberikan impact yang luar biasa dalam segala aspek kehidupan masyarakat, terutama dunia pendidikan. Era digital bukanlah digitalisasi konten belaka, era digital adalah sebuah masa dimana mulai munculnya "media baru" yang dapat dimanipulasi, bersifat jaringan yang saling terintegrasi, bersifat padat, serta interaktif. Contoh konkretnya adalah internet, website, komputer multimedia, hingga CD-ROMS. Hal ini sejalan dengan apa yang dikemukakan oleh Toffler. Menurut Toffler dalam Rustam, gelombang peradaban manusia di bagi menjadi tiga fase. Pertama, saat manusia menemukan pola bercocok tanam dan mulai hidup menetap. Pola menetap merupakan sebuah perkembangan yang luar biasa, karena pada awalnya manusia hidup nomaden (berpindah-pindah) dengan mata pencaharian meramu. Ini jelas salah satu bentuk revolusi besar, karena apa? Karena manusia mau dan mampu untuk mengubah kebiasannya yang sudah berlangsung lama.

Kedua, gelombang peradaban atau dikenal dengan istilah revolusi industri. Istilah revolusi industri muncul di awali oleh rangkaian inovasi mesin cetak oleh J. Guttenberg sekitar abad ke-15. Dampak dari pembuatan mesin cetak ini, hasil pemikiran manusia dapat digandakan sehingga dapat dibaca oleh orang banyak. Pelan namun pasti, pemikiran-pemikiran mulai berkembang hingga akhirnya booming dengan istilah revolusi industri. Ketiga, pada fase ini Toffler belum menemukan istilah yang tepat untuk mendefiniskan gelombang ke tiganya ini. Namun, banyak orang yang menyebutnya sebagai "abad informasi” atau "abad 


\section{Yogik Delta Hermawan}

elektronik". Sedangkan di Indonesia lebih dikenal dengan istilah era digital (Rustam, 2016: 48-49).

Selain itu dijelaskan bahwa "The digital era has transformed the way many of us live and work by creating a society and economy that is ever more attuned to knowledge, whether that knowledge is content-laden and therefore scientifically factual, or instead is content-free and therefore reliant on emotions, or indeed any combination in between". Poin penting dalam era digital seperti sekarang ini bukanlah siapa yang mempunyai kekuasaan, melainkan siapa yang mampu berinovasi dalam konteks teknologi. Kita harus mampu menerima kenyataan bahwa ponsel lebih populer daripada telepon rumah, itu merupakan fakta yang tidak terbantahkan (Georgios Doukidis, 2004: chapter 1).

Rodrigo Chaves selaku kepala perwakilan Bank Dunia untuk Indonesia dalam Mudarya, mengatakan bahwa pada tahun 2018 kualitas pendidikan Indonesia masih tergolong rendah. Meskipun akses pendidikan untuk masyarakat sudah meningkat signifikan. Rendahnya kualitas pendidikan Indonesia terlihat dari jumlah buta huruf yang masih tinggi. Menurutnya angka buta huruf di Indonesia mencapai 55 persen untuk anak usia 15 tahun. Melihat fakta di atas, tentu ada yang perlu dibenahi dalam pendidikan di Indonesia. Dibutuhkan kesadaran dan peran serta dari semua komponen pendidikan yang ada, mulai dari unsur atas hingga akar rumput. Karena ke depan tantangan dalam dunia pendidikan akan terus berkembang semakin kompleks. Terutama tantangan bagi seorang pendidik. Berdasarkan ketentuan yang ada, seorang pendidik wajib mempunyai empat kompetensi dasar yaitu kompetensi pedagogik, kompetensi profesional, kompetensi kepribadian, dan kompetensi sosial. Namun, tidak hanya sampai disitu. Seorang pendidik juga harus siap menghadapi begitu dinamisnya perkembangan yang ada di masyarakat. Saat ini pendidik dihadapkan pada tantangan dalam merespon perkembangan digital atau teknologi yang begitu pesat. (Mudarya, 2019: 4-6)

Di era digital seperti sekarang ini, seorang pendidik perlu mengubah cara mengajarnya, dari yang biasanya bersifat konvensional harus lebih menyenangkan 


\section{Yogik Delta Hermawan}

dan menarik bagi siswa. Pendidik atau guru juga dituntut menjadi seorang fasilitator, motivator, inspirator, mentor, dan empati sosial. Jika komponen tersebut tidak diwujudkan maka peran pendidik dapat digantikan oleh teknologi. Pendidik juga harus mampu membangun suasana atau atmosphere yang dapat memenuhi kebutuhan peserta didik, yaitu needs for competence, maksudnya adalah interaksi dalam pembelajaran mampu membuat peserta didik merasa bisa. Hal ini bisa dilakukan dengan memberikan berbagai macam reward. Needs for autonomy, maksudnya adalah peserta didik diberikan kebebasan dan kepercayaan dalam kegiatan belajar-mengajar di kelas. Needs for relatedness, memberikan pemahaman kepada peserta didik tentang pentingnya kehadiran sebuah kelompok bagi dirinya. Tujuannya adalah guna memupuk jiwa kolektivitas dan saling mendukung satu sama lain. Serta subtainable learning, yaitu memberikan pemahaman kepada peserta didik untuk mampu dan bersiap dalam menghadapi era digitalisasi dalam berbagai aspek kehidupan (Susilo, 2019: 9-10).

Fakta di atas merupakan tantangan bagi pendidik dalam konteks era digital, padahal saat ini selain di hadapkan pada perkembangan era digital, pendidik juga harus merespon adanya pandemi Covid-19 yang melanda negeri ini. Tentu seorang pendidik harus bekerja lebih keras lagi. Karena akibat dari adanya pandemi ini, kegiatan belajar mengajar harus dilaksanakan di rumah masing-masing, atau istilahnya adalah pembelajaran daring (dalam jaringan). Mau tidak mau, pendidik harus beradaptasi dengan situasi ini. Pembelajaran yang biasanya face to face di kelas, berubah menjadi pertemuan "maya" yang mungkin mengurangi esensi dari pembelajaran itu sendiri. Karena feel sebuah pertemuan juga akan sangat mempengaruhi suasana dari kegiatan belajar-mengajar. Mengutip fakta dari portal berita Nasional CNN Indonesia, kegiatan pembelajaran daring masih banyak mengalami kendala. Salah satunya adalah di daerah Batam. Keterangan seorang pendidik di sana, proses belajar-mengajar berbasis digital (online) masih sangat sulit untuk dilakukan. Hal ini diakibatkan oleh beberapa faktor mulai dari keterbatasan alat teknologi, gagap teknologi, hingga pengaruh signal dari provider. 


\section{Yogik Delta Hermawan}

Kasus seperti ini juga ditemukan di daerah Bogor dan beberapa daerah lain di Indonesia (CNN Indonesia: 2020).

Berbagai tantangan ataupun kendala yang dihadapi para pendidik harus segera mendapatkan jalan keluarnya. Hal ini penting, agar tujuan pendidikan dapat dicapai dengan maksimal. Berikut adalah beberapa upaya yang dapat dilakukan oleh para pendidik guna merespon perkembangan era digital yang semakin pesat ditambah dengan adanya pandemi Covid-19 seperti sekarang ini.

a. Pendidik wajib mengikuti perkembangan teknologi

Di era digital, pendidik tidak boleh gagap akan teknologi. komputer, gawai, hingga alat elektronik lainnya yang menunjang kegiatan pembelajaran harus menjadi keseharian mereka. Media sosial dan berbagai sumber informasi juga harus dipahami para pendidik. Sehingga impact nya adalah dalam menjalankan profesi keguruannya seorang pendidik akan kaya dengan materi dan metode. Implikasinya adalah peserta didik tidak akan memandang sebelah mata kemampuan pendidik.

b. Pendidik harus memberikan pembelajaran yang relevan dengan peserta didik

Belajar merupakan sebuah kegiatan positif, dan akan lebih bermakna ketika peserta didik memahami aplikasi praktis terkait infomasi yang mereka terima. Isi harus spesifik, dan ringkas. Hal ini penting, karena era digital memiliki subjek yaitu generasi milenial. Generasi milenial haus akan informasi dan cenderung mencarinya sendiri jika seorang pendidik tidak mampu menyajikan apa yang mereka anggap relevan dengan pembelajaran. Begitu banyak informasi yang tersedia di dunia maya, mereka merasa tidak perlu belajar setiap hal dengan segera. Sebaliknya, mereka ingin di ajari bagaimana cara yang tepat untuk menemukan apa yang mereka butuhkan (Mahyuddin, 2019: 112-113).

c. Membangun pondasi pendidikan karakter yang kokoh

Dalam konteks era digital tentu pendidikan karakter merupakan suatu hal yang penting dimiliki oleh pendidik, selain juga peserta didik. Pesatnya perkembangan IPTEK membuat informasi yang diterima “sangat liar" dalam 


\section{Yogik Delta Hermawan}

konteks infomasi yang positif maupun negatif. Seorang pendidik harus mampu melakukan filterisasi, sebelum ia mengajarkan sesuatu kepada peserta didik. Salah satu kuncinya adalah dengan memiliki karakter yang kuat. Untuk memiliki itu harus paham betul tentang makna pendidikan karakter. Karakter selalu berhubungan dengan moral seseorang, karakter yang ideal adalah dengan menganut apa yang dikerjakan oleh Rasulullah SAW. Karena apa? Karena pada dasarnya Allah SWT mengutus Rasulullah SAW salah satunya adalah untuk menyempurnakan akhlak manusia. Oleh karena itu, seorang pendidik setidaknya harus menjaga karakter kebangsaannya dari berbagai macam ideologi yang ada. Misalnya hedonism hingga radikalisme yang tidak sesuai dengan Pancasila dan NKRI. Selain itu, seorang pendidik juga harus mampu mentransformasikan nilai-nilai pendidikan karakter bagi peserta didiknya, menurut Character Education Quality Standards terdapat 11 prinsip guna mewujudkan pendidikan karakter yang efektif. Namun penulis akan menyampaikan empat poin yang relevan dengan situasi sekarang, di antaranya mempromosikan nilai-nilai dasar etika sebagai basis karakter; menciptakan komunitas sekolah yang memiliki kepedulian; memiliki cakupan terhadap kurikulum yang bermakna dan menantang serta menghargai siswa; serta memfungsikan keluarga dan anggota masyarakat sebagai mitra dalam usaha pembangunan karakter peserta didik (Abdul Majid, 2017: 109).

d. Terus amati perkembangan budaya

Sangat penting bagi seorang pendidik untuk senantiasa mengikuti dan mengamati denyut perkembangan budaya populer. Tujuannya adalah memberikan pemahaman bagi pendidik untuk mengetahui lebih dalam tentang peserta didik. Banyak cara yang dapat dilakukan, misalnya membaca buku-buku mutakhir, membaca perkembangan informasi yang beredar di masyarakat, hingga berselancar menggunakan media sosial. Dengan hal tersebut, akan banyak membantu guru dalam memahami gaya hidup generasi anak didiknya. Terkait dengan budaya populer masa kini, Thomas D. Zweifel dalam Lubis, mengungkapkan bahwa mereka (generasi muda) tidak lah berbicara dengan bahasa anda. Mereka mungkin 


\section{Yogik Delta Hermawan}

tidak dibesarkan dengan nilai-nilai yang anda pegang. Apakah itu aneh atau bukan, pertumbuhan mereka ditemani dengan laptop, surat elektronik, dan permainan komputer. Mereka terbiasa berkomunikasi dengan mesin bukan manusia. Itulah potret generasi muda saat ini (Lubis, 2019: 12-13).

e. Pendidik harus aktif melakukan penelitian

Sekarang ini adalah era digital, ada juga yang mengatakan era globalisasi. Esensi dari ke dua istilah tersebut sebenarnya sama. Guna menyikapi hal tersebut, pendidikan harus melakukan reformasi dan inovasi dalam kegiatan belajar mengajar secara berkelanjutan. Diperlukan dukungan empirik yang dihasilkan dari sebuah penelitian. Inilah yang menjadi alasan kuat, mengapa seorang pendidik harus paham dan mau untuk melakukan sebuah penelitian (Mahyuddin, 2019: 113).

Pendidikan merupakan sebuah sistem yang di dalamnya terdapat beberapa unsur pendukung yang saling berkaitan. Mulai dari pendidik, peserta didik, kurikulum, hingga sarana dan prasarana. Semua unsur tersebut bekerja secara beriringan dan saling mempengaruhi. Namun dalam pembahasan ini, penulis akan memberikan gambaran terkait "Pendidik, teknologi, dan pandemi Covid-19". Ketiga kata tersebut sangat relevan dengan judul artikel di atas, sekaligus akan menjelaskan kondisi yang ada di masyarakat sekarang ini. Pada hakikatnya, pendidik adalah setiap orang yang mengabdikan dirinya guna menyampaikan ilmu pengetahuan kepada orang lain. Pendidik juga dipandang sebagai orang yang memiliki wibawa, terhormat, dan profesional dalam hal pengajaran serta menginternalisasikan nilai-nilai mulia terhadap peserta didik (Samsul Nizar, 2018: $4)$.

Pendidik era dahulu dan sekarang tentu memiliki perbedaan yang signifikan. Zaman dahulu, jauh sebelum era globalisasi hingga era digitalisasi seperti saat ini. Profesi pendidik merupakan sebuah profesi yang sangat dihormati seperti priyayi. Bahkan di dalam acara perayaan tertentu, pendidik duduk dideretan utama. Secara ekonomis, penghasilan pendidik saat itu sudah sangat memadai 


\section{Yogik Delta Hermawan}

bahkan lebih. Ini memberikan dampak yang besar bagi psikologis mereka, selfesteem, hingga wibawa mereka. Hampir tidak pernah terdengar berita, ada seorang pendidik yang dilaporkan oleh wali murid karena "menghukum" anak didiknya. Karena pada saat itu, para wali murid sudah paham betul tentang makna "hukuman" yang diberikan kepada peserta didik jika melanggar. Namun kini, keadaan pendidik mulai berubah. Profesi pendidik adalah profesi yang "kering" bahkan "gersang". Maksudnya adalah kebanyakan pendidik dalam menjalankan profesinya hanya untuk mempertahankan kepulan asap di dapur mereka (tapi ini tidak berlaku untuk semua pendidik). Sementara itu, wibawa seorang pendidik juga sudah kian merosot. Akhir-akhir ini sering kita melihat, pendidik yang dipidanakan akibat tidak terimanya orang tua murid akan perilaku pendidik tersebut kepada anaknya. Tentu ini adalah sebuah ironi. Dalam konteks ekomonis, masih banyak pendidik di Indonesia yang mendapat gaji di bawah standar. Inilah beberapa fakta yang terjadi dan di alami oleh pendidik kita (Muhibbin, 2016: 220).

Dinamika dunia pendidikan lebih kompleks dari yang sudah di sebutkan di atas. Saat ini, pendidik di hadapkan pada situasi yang mengharuskan kegiatan belajar-mengajar dilakukan dari rumah. Ini berlaku mulai dari taman kanak-kanak hingga perguruan tinggi. Dampaknya adalah pembelajaran harus dilakukan melalui daring. Artinya dalam pembelajaran tersebut hadir sebuah teknologi. kenapa hal tersebut terjadi? karena di Indonesia sedang terjadi pandemi Covid-19 yang mengharuskan seluruh kegiatan belajar-mengajar dikerjakan dari rumah. Apa itu Covid-19? Covid-19 merupakan sebuah virus yang menyerang saluran pernapasan manusia dan bersifat zoonosis, artinya adalah penyakit yang dapat ditularkan antara hewan dan manusia. Virus ini mulai muncul di wilayah Wuhan Cina sekitar bulan Desember 2019, hingga akhirnya WHO mendeklarasikan sebagai pandemi global. Dikarenakan penyebarannya yang semakin meluas diberbagai Negara di dunia. Berdasarkan keterangan dari para ahli dunia, virus ini dimungkinkan berasal dari kelelawar. Karena hewan ini telah berevolusi untuk hidup berdampingan dengan banyak virus, dan mereka merupakan titik awal adanya wabah SARS yang terjadi 


\section{Yogik Delta Hermawan}

sebelumnya (alodokter.com/virus-corona: 2020). Di Indonesia, Covid-19 sudah mengakibatkan banyak korban jiwa dan ribuan orang dirawat. Selain itu, virus ini juga memberikan dampak dalam bidang ekomoni, sosial, politik, hingga pendidikan. Karena Covid-19, pendidikan di Indonesia harus beradaptasi dengan situasi baru yang sebelumnya sama sekali tidak pernah terbayangkan. Yaitu belajar dari rumah selama berminggu-minggu. Bahkan, agenda besar Ujian Nasional juga harus ditiadakan. Sebagai salah satu cara guna memutus penyebaran virus ini. Implikasi nyata yang harus dihadapi oleh pendidik adalah meningkatkan kemampuan dalam berteknologi. Karena pembelajaran hanya melalui satu jalur, yaitu daring. Kemudian muncul pertanyaan besar. Apakah peran pendidik akan tergerus dengan hadirnya teknologi karena adanya pandemi ini? Pada dasarnya teknologi merupakan sebuah sarana "pembantu" yang memiliki beberapa manfaat di dalamnya. Secara umum manfaat teknologi adalah meningkatkan dan mengefektifkan sistem pendidikan dari yang bersifat klasikal menjadi terbuka sesuai dengan minat dan kemampuan siswa; dengan teknologi, peserta didik dapat mengikuti pendidikan secara tidak terbatas. Baik dalam lingkup tempat dan waktu; pembelajaran dapat dilaksanakan dengan lebih fleksibel; serta mempermudah dalam penyampaian infomasi baik secara verbal maupun non verbal (Gusmaneli, 2012: 168).

Melihat manfaat teknologi dalam bidang pendidikan, maka sudah seharusnya dunia pendidikan lebih welcome dengan hadirnya teknologi. Pendidik tidak mungkin bisa menghindari teknologi, yang bisa dilakukan hanya bagaimana mengatur dan mengaplikasikan teknologi tersebut dalam kegiatan pendidikan. Terutama di tengah kondisi pandemi Covid-19 seperti ini. Meskipun teknologi hadir dan mengisi dunia pendidikan, tidak otomatis akan mampu menggantikan peran seorang pendidik. Karena esensi pembelajaran bukan hanya transfer of knowledge, melainkan transfer of value. Terdapat unsur mengembangkan misi kemanusiaan, membangun peradaban manusia dengan cara menggali, menyadarkan, menggerakkan jiwa setiap peserta didik menuju kebenaran dan 


\section{Yogik Delta Hermawan}

kebaikan. Sehingga tujuan akhirnya adalah pembentukan karakter yang benar-benar sesuai dengan kepribadian bangsa Indonesia. Menurut Al-Ghazali dalam M. Shabir, mengatakan bahwa tugas dan tanggung jawab utama seorang pendidik di antaranya adalah pendidik harus mampu menaruh rasa kasih sayang terhadap murid; tidak mengharapkan balas jasa; memberikan nasehat kepada peserta didik dalam setiap kesempatan; mencegah peserta didik dari perbuatan tercela; serta pendidik harus menjalankan ilmunya dan jangan pernah berdusta (M. Shabir, 2015: 226). Jika komponen di atas dijalankan dengan maksimal maka peran pendidik sudah pasti tidak akan pernah tergantikan oleh teknologi dalam bentuk apapun. Dengan kata lain eksistensi pendidik dalam menghadapi pandemi Covid-19 di era digital masih ada.

Hal senada juga diungkapkan oleh mantan Menteri Pendidikan sekaligus Gubernur DKI Jakarta Anies Baswedan dalam kompas.com, mengatakan bahwa teknologi hanya sebatas fasilitas dalam kegiatan mengajar. Pendidik tetap memiliki peran signifikan dalam kegiatan mengajar, terutama dalam hal memberikan nilainilai positif, hingga memberikan inspirasi kepada peserta didik. Pendidik tidak mungkin bisa digantikan oleh teknologi (Kompas.com: 2018). Presiden Joko Widodo dalam kabar24 juga mengungkapkan hal yang sama, namun lebih spesifik lagi. Yaitu guru tetaplah seorang guru, tidak bisa digantikan oleh teknologi secanggih apapun. Kehadiran guru sangat diperlukan dalam hal memberikan pengawasan kepada peserta didik dalam pemanfaatan teknologi (fasilitator). Karena tanpa kehadiran pendidik, justru akan menjadi boomerang bagi peserta didik itu sendiri (kabar24.bisnis.com: 2019).

Oleh karena itu, melihat berbagai macam data dan fakta di atas, maka peran pendidik yang seharusnya dilakukan agar tidak tergerus perkembangan teknologi di tengah pandemi adalah seorang pendidik harus menjadi sumber belajar bagi peserta didik; pendidik harus menjadi fasilitator; pendidik harus menjadi pengelola proses pembelajaran sehingga mampu memegang kendali penuh iklim pembelajaran; pendidik harus mampu menjadi demonstrator, maksudnya adalah pendidik mampu 
menunjukkan sikap yang inspiratif bagi siswa; pendidik harus mampu menjadi seorang pembimbing; pendidik merupakan seorang motivator, kunci semangat dan tumbuhnya motivasi dalam diri setiap peserta didik adalah pada pendidiknya selain dari peserta didik itu sendiri; pendidik harus mampu menjadi seorang evaluator, yaitu melakukan evaluasi terhadap semua hasil belajar yang telah dilakukan sebelumnya; serta mampu menjadi seorang inovator. (Wartomo, 2016: 8-9).

\section{Simpulan}

Era digital seperti sekarang ini dan ditambah dengan situasi pandemi Covid19, menjadikan peran dan tanggung jawab seorang pendidik menjadi lebih besar. Baik dalam konteks mengajar maupun mendidik. Seorang pendidik harus mampu menghadapi berbagai macam tantangan yang ada dengan melakukan beberapa hal. Mulai dari mengikuti perkembangan teknologi, memberikan pembelajaran yang relevan dengan peserta didik, membangun pondasi pendidik karakter yang kokoh, aktif mengamati perkembangan budaya, hingga aktif melakukan penelitian. Selain itu, pendidik juga harus mampu menjadi seorang fasilitator, demonstrator, dan motivator. Jika semua upaya tersebut sudah dilakukan dengan maksimal, dapat dipastikan peran seorang pendidik tidak dapat digantikan oleh teknologi secanggih apapun. Karena pada dasarnya, kehadiran teknologi hanyalah sebagai pelengkap, bukan unsur utama dalam pendidikan. Pendidik tetaplah pendidik, kehadirannya selalu dinanti oleh para peserta didik. Pembelajaran bukan hanya transfer of knowledge semata, melainkan juga memerlukan adanya transfer of value. Itu hanya bisa dilakukan oleh seorang pendidik, meskipun di tengah pandemi Covid-19 seperti sekarang ini.

\section{Daftar Pustaka}

Aji, Rustam. 2016. Digitalisasi Era Tantantang Media (Analisis Kritis Kesiapan Fakultas Dakwah dan Komunikasi Menyongsong Era Digital). Islamic Communication Journal, Vol. 01, No. 01, Mei - Oktober 2016: 43 - 54. 
Amanda Kusumawardhani Amanda. Jokowi: Guru tak Bisa Digantikan Mesin. Diakses $\begin{array}{llll}\text { tanggal } 04 & \text { Mei }\end{array}$ https://kabar24.bisnis.com/read/20190705/15/1120754/jokowi-guru-tak-bisadigantikan-mesin

Barni, Mahyuddin. 2019. Tantangan Pendidik di Era Milenial. Transformatif (Journal Islamic Studies), Vol. 3, No. 01 April 2019: 99 - 116.

Budiman, Haris. 2017. Peran Teknologi dan Informasi dalam Pendidikan. AlTadzkiyyah: Jurnal Pendidikan Islam, Volume 8 No. I 2017: 34-37

Doukidis, Georgios et al. 2004. Social and Economic Transformation in the Digital Era. United States of America: Idea Group Publishing.

Grafura, Lubis dan Ari Wijayanti. 2019. Spirit Pedagogi di Era Disrupsi. Yogyakarta: Laksana.

Gusmaneli. 2012. Dampak Teknologi Pendidikan Terhadap Peranan Guru di Masa Depan. Jurnal Al-Ta'lim, Jilid 1, No. 2 Juli 2012: 166 - 172.

Harususili, Yohanes Enggar. Anies Baswedan: Guru Tidak Dapat Digantikan Teknologi. Diakses $\quad$ pada $30 \quad$ April 2020. https://edukasi.kompas.com/read/2018/09/27/18073381/anies-baswedan-gurutidak-dapat-digantikan-teknologi

Harususili, Yohanes Enggar. Mendikbud Nadiem: Mulai Senin Siswa Bisa Belajar dari Rumah lewat TVRI. Diakses tanggal 30 April 2020. https://www.kompas.com/edu/read/2020/04/09/182324371/mendikbud-nadiemmulai-senin-siswa-bisa-belajar-dari-rumah-lewat-tvri?page=all

Majid, Abdul dan Dian Andayani. 2017. Pendidikan Karakter Perspektif Islam. Bandung: PT Remaja Rosdakarya.

Mudarya, I Nyoman. 2019. Kuantitas dan Kualitas: Era Baru Pendidikan Indonesia. Daiwi Widya Jurnal Pendidikan Vol. 06 No. 3 Edisi Desember 2019: 4-6.

Nizar, Samsul dan Zainal Efendi H. 2018. Pendidik Ideal (Bangunan Character Building). Depok: Prenadamedia Group.

Pane, Merry Dame Cristy. Virus Corona. Diakses tanggal 17 Juli 2020. https://www.alodokter.com/virus-corona

Syah, Muhibbin. 2016. Psikologi Pendidikan dengan Pendekatan Baru. Bandung: PT Remaja Rosdakarya.

Tim CNN Indonesia. Corona, Kelas Daring, dan Curhat 2 Guru untuk Orang Tua. Diakses tanggal 30 Mei 2020. https://www.cnnindonesia.com/gayahidup/20200330165053-284-488368/corona-kelas-daring-dan-curhat-2-guruuntuk-orang-tua. 
U, M. Shabir. 2015. Kedudukan Guru Sebagai Pendidik (Tugas dan Tanggung Jawab, Hak dan Kewajiban, dan Kompetensi Guru). Auladuna, Vol. 2, No. 2 Desember 2015: $221-232$.

Utomo, Susilo Setyo. 2019. Guru di Era Revolusi Industri 4.0. Diakases pada 30 April 2020.

https://eprints.uny.ac.id/65069/1/GURU\%20DI\%20ERA\%20REVOLUSI\%20IN DUSTRI\%204.0.pdf.

Wartomo. 2016. Peran Guru dalam Pembelajaran Era Digital. Prosiding Teти Ilmiah Nasional Guru (TING) VIII, Yogyakarta. Diakses pada 30 April 2020. http://repository.ut.ac.id/6500/1/TING2016ST1-26.pdf 
QUALITY

Volume 8, Nomor 2, 2020, 303-318 